\title{
4 \\ Songs in sheds: \\ some thoughts on the sociology of Fiji elections
}

\section{Paul Geraghty ${ }^{\uparrow}$}

The way elections are conducted in Fiji differs in many ways from the way they are conducted ovasis (a Fiji English term that usually means Australia and New Zealand, but can also include the United Kingdom and other places where kaivalagi - people of European origin or 'white' people - reside). These differences are, at least in part, due to indigenous Fijian customs. In this chapter, I attempt to answer such questions as why, in elections in Fiji, there is little or no heckling but lots of prayers and hymns, why people turn up for elections in their Sunday best, and the origin and function of that peculiarly Fijian institution, the electoral shed and the songs sung therein.

\section{History}

The first general election in Fiji was in $1963 .^{2}$ This was the first time that Fijians had universal suffrage and participated in a secret ballot. On the other hand, Indians in Fiji had been voting for representatives to the Legislative Council since 1929, and Europeans since $1904 .^{3}$ Fijians had taken little interest in national affairs, being more concerned with Fijian society and local Fijian politics, in particular the Bose Levu Vakaturaga (Great Council of Chiefs). However, they were not total strangers to the concept of elections. As with many aspects of the westernization of Fijian society, it was probably the Methodist Church that introduced the Fijians to electoral voting, with the Fijian administration not far behind. Some form of voting had existed in the 
Methodist Church since 1866, ${ }^{4}$ and the practice of electing office holders, such as turaganikoro (village headmen) and mata ni tikina (district representatives), by laveliga (show of hands) or by vakaio (acclamation) seems to go back a long way, probably to the 19 th century. ${ }^{5}$

The Fijian word currently used for 'election' or 'ballot' is veidigidigi, ${ }^{6}$ which is recorded as early as $1941 .^{7}$ Etymologically, it means 'many people choosing someone' - so is a very apt neologism, and whoever its coiner was deserves credit. The same word was used in the Bible - the current translation of which dates from 1900 - but there it seems to have a different meaning, translating as 'partiality' (1 Timoci 5:21) and 'make distinctions' (Jemesa 2:4). There is at least one alternative form, veidigitaki (literally 'one person choosing another'), which appeared in the Fijian language newspaper Volagauna in $1963,{ }^{8}$ but I have been unable to determine whether or not it had any general currency at that time. Certainly, it is not used today.

It is commonly believed that 'consensus' is the traditional Pacific way of making decisions, but this notion appears to be relatively modern. Before the arrival of Christianity and western government, decision-making was fairly exclusively by way of lewa vakaturaga (chiefly decision) - though if the people for whatever reason did not like the lewa of a particular turaga, they often found ways of getting rid of him or her and appointing another. With the westernization of political institutions, at least at a certain level, decisions were made by the will of the majority, and determined by voting. A now retired member of a certain provincial council told me that voting was only recently, within the last 10 or 20 years, replaced by 'consensus' - usually a steamrolling by the chair.

\section{Politics is religion, campaigning is preaching}

In the Fijian worldview, politics is, if not exactly religion, something very close to it. One indication - though I am always wary of reading too much hidden meaning into homonyms, as many anthropologists do - is that vunau, the word for 'preach', is also used for political campaigning. Indeed, political speeches are usually listened to with the silence and respect afforded a sermon, even when the 'congregation' patently has no intention of voting for the speaker.

Heckling is a sine qua non of campaigning in places like Britain ${ }^{9}-$ but is very rare in the Fijian context, although it does occur to some extent among 
the Indian community. In nearly 30 years of living in Fiji and reading The Fiji Times daily (and other newspapers occasionally), I have, to my recollection, only come across the word 'heckle' once - and even then it was spelled 'hackle'.

\section{The shed}

To most native speakers of English, a shed is a small building for storing gardening tools or coal for the fire to tide you over the long winters. In Fiji, however, the word has a unique meaning. Essentially, it is a temporary opensided structure, usually with bamboo posts and a corrugated iron roof, erected for many kinds of gatherings. In colonial times, there was a roaring trade in bamboo from the bilibili (bamboo rafts) that brought bananas down to Nausori by way of the Wainimala and Wainibuka rivers, precisely for this purpose; but this has all but ceased today.

The best-known Fijian word for the shed is vakatunuloa (sometimes shortened to tunuloa), on the origins of which there has been much speculation. It may have some connection with Tunuloa, on the Natewa peninsula in Cakaudrove, but the exact nature of the connection is obscure. The earliest reference is in Cargill's dictionary of Lakeba Fijian, ${ }^{10}$ where vakatuniloa is defined as 'a porch or shade', and its Rewa equivalent is given as vakatunuloa. The 1839 definition suggests that it may have had a rather different meaning at that time. The word is not found in the first-published dictionary of Fijian, ${ }^{11}$ but does appear in the most recent Fijian dictionary, in which both tunuloa and vakatunuloa are defined as 'shed'. ${ }^{12}$ There are also a number of regional names for the same structure, such as bolabola and covacova.

In Fiji Hindi, the word for shed is remarkable in that it has at least four different forms. In most of Vanualevu it is jhaap, in most of Vitilevu it is mad'haa (the apostrophe after the ' $\mathrm{d}$ ' indicates that it is retroflex), in some parts of rural Nadi and Bua it is pandaal, and the Fiji-English shed is used in Suva and Lautoka. It would be interesting to find out the original meaning or meanings of these terms. Given that none of them is a borrowing from Fijian, it would seem that this artefact was also present in traditional Indian culture, though some of its functions may well have been adapted from the use of the vakatunuloa in Fijian society. 
The function of the shed is to shelter, fodder and ply with grog, visitors at a gathering, most frequently a funeral, but also weddings and, in Fijian society, vakataraisulu (the lifting of mourning for a chief) and, particularly in the islands, vakatawase - new year celebrations - when swarms of urbanites return to their villages for a week or two of celebration and feasting on fish and lairo (land crabs). The function of sheds at elections is similar, but they are erected by political parties or independent candidates, and function like the exclusive lounges run by airlines at airports, except that the customers are provided with the kinds of food and drink that are more popular in Fiji. The expectation is the same: that in return, the customers will continue to 'fly with that particular airline' - or vote for a particular party. No modern election is complete without some party complaining about the agepije or liumuri ${ }^{13}$ of voters who go through their sheds and enjoy their palau and yaqona and then go and tick the name of some other party on the ballot form ${ }^{14}$ - and complaining that the sheds are an inordinate drain on resources. But next election there they will be again, because voters have come to expect them. It could also be argued that they are symbols of the political power of the party or of the individual erecting and financing them. I believe that they are a relatively modern institution - certainly they seem not to have been present during the 1963 general election.

In Fijian custom, large gatherings - such as tevutevu (exchange of wedding gifts) and vakataraisulu - are subsumed under the name solevu, and I would like to suggest that, for Fijians, the election is a kind of solevu. Hazlewood ${ }^{15}$ defines a solevu as 'a large number of people gathered together to present property to a chief, or to a town, on which occasion they generally meke (dance) and make magiti (large quantities of food); a kind of Fijian ball; feast, or fair'. The presence of the vakatunuloa or shed is one of the indications of this functional equivalence, but there are others. Clothing is one. Fijian dress codes are relatively strict (at least from the perspective of most westerners); when a Fijian goes out to a public occasion, he or she will dress appropriately. They will dress vakavavalagi (in the western fashion, e.g. trousers or jeans for men, skirts or jeans for women) if they are going to the cinema, or a concert of western music, or a western-type gathering, such as Suva's annual Hibiscus Festival. But if it is a vakaviti (traditional Fijian) occasion, such as most religious 
gatherings and vanua-based fund-raising events called adi (which are in many respects similar to the Hibiscus Festival), then 'traditional' Fijian dress is 'de rigeur' - sulu vakataga (pocket sulu) for men, and usually suluira (ankle-length under-skirt) and jaba (knee-length dress) for women. ${ }^{16}$ For elections, Fijians typically dress in this traditional fashion. In many parts of Fiji, various groups of participants in the recent elections, including even groups of officials, chose to buy and wear specially tailored uniforms - kalavata or puleta - in much the same way as happens with solevu.

\section{The songs}

The songs that are sung in election sheds by Fijians, particularly when victory has been announced but often before that too, are taken from a very limited repertoire of songs that are associated with solevu. They could almost be numbered on the fingers of two hands: Da mai laveta, Lomaloma, O Bau na yanuyanu, Liwavi au na tokalau, Noqu vanua, and not many more. They are songs of cibi-triumph. ${ }^{17}$ They are not songs that would normally be played on the radio, not songs that anyone would request on any of Fiji's numerous phone-in radio programs. They are patriotic songs, expressing pride in the nation or a particular region. Maybe not coincidentally, they all appear to have been composed in the 1950s or 1960s, so would have been popular at the time of the first general election in which Fijians participated. They belong to a very limited canon of songs that are appropriate in a very restricted context: solevu - and elections. $^{18}$ 


\section{Notes}

1 My heartfelt thanks are due to Jon Fraenkel, Mosmi Bhim, Bruce Yeates, Adi Tiriseyani Naulivou, Vani Catanasiga, Jiaoji Rarubi, Andrew Thornley and Eremasi Tamanisau for their generous help with this chapter. Blame for any faults, however, is entirely my own.

2 Ravuvu, A. D. 1988. Development or Dependence: The Pattern of Change in a Fijian Village. Institute of Pacific Studies, University of the South Pacific, Suva. pp.80-81.

3 Meller, N. \& James A. 1968. Fiji Goes to the Polls: The Crucial Legislative Council Elections of 1963. East-West Center Press, Honolulu, pp.11-13.

4 Thornley, A. 2002. Exodus of the I Taukei: The Wesleyan Church in Fiji 1848-74. Institute of Pacific Studies, University of the South Pacific, Suva. pp.481-483.

5 For instance, Native Regulations published in 1949 stipulate that village representatives to the district council should be elected by a show of hands (A Lawa I Taukei 1949:146).

6 Long vowels are often indicated by means of a macron - a straight line over the vowel. As macrons are not available with this typeface, for the sake of linguistic accuracy, in the following words the underlined vowels are the long ones: veidigidigi, lewa , solevu and puleta.

7 Capell, A. 1941. A New Fijian Dictionary. Australasian Medical Publishing Co., Sydney.

8 Meller \& James. 1968. Fiji Goes to the Polls. p.145.

9 In a mock election held at my secondary school, Rugby School in England, the Tory candidate planted a pseudo-socialist heckler in the audience and had him shout out, 'What about the workers?' To which the candidate instantly replied, 'We are the workers - workers for a better Britain!'

10 Cargill, D. et al. 1839. Feejeean Dictionary. MS A 2065, Mitchell Library, Sydney.

11 Hazlewood, D. 1850. A Feejeean and English Dictionary: With Examples of Common and Peculiar Modes of Expression. Vewa, Feejee [Viwa, Fiji], Wesleyan Mission Press.

12 Capell. 1941. A New Fijian Dictionary.

13 Both mean 'duplicity' or 'treachery' - the first from Hindi, the second from Fijian - and both are used in Fiji English.

14 Lal, 'Elections' (n.d.:2) quotes a doctor who was defeated in an election as saying, 'The voters are treacherous bastards. They will drink your yaqona, eat your palau and vote for someone else'. Lal (n.d.:5) also reports that 'a Labour strategist tells his supporters to pluck coconuts (Labour symbol) by climbing the branches of the mango tree (Federation symbol). Translation: drink your opponents' yaqona, eat their food, go through their sheds, but vote for Labour' Hazlewood. 1850. A Feejeean and English Dictionary.

16 Geraghty, P. 1997. 'The ethnic basis of society in Fiji', in Lal, B.V. \& Vakatora, T.R. (eds). Fiji Constitution Review Commission Research Papers Fiji in Transition 1:1-23. School of Social and Economic Development, University of the South Pacific, Suva.

17 Note that the so-called challenge of the Fiji national rugby team, the cibi, is not a challenge at all (which would be a bole) but a chant of victory.

18 Although this paper focuses primarily on the Fijian community, I would like to offer also a few comments on similarities and differences in the Indian community. Both emphasize prayer as part of election meetings, and in both there is a tendency to dress formally at meetings and during the elections, though there is overall more formality, and less noise, in Fijian meetings (Lal n.d. pp. 6-7; Mosmi Bhim pers. comm. June 2006.). 